\section{NY hospitals win education subsidy}

No one likes to be compared with a bushel of corn but that is the way medical residents will be counted in New York State for the next six years. In an inventive plan to cushion themselves against sweeping changes in the way physician-training is funded, the state's research hospitals have persuaded the federal Health Care Financing Administration to pay them according to current formulas even though the actual number of positions for new residents will be gradually reduced.

As part of its commitment to graduate medical education (GME), Medicare pays hospitals approximately US $\$ 100,000$ a year for every resident, even though residents' salaries are ususally closer to $\$ 40,000$. Hopitals use the difference to support a variety of academic programs, including some funding of clinical research. In New York, hospitals will continue to receive GME funds even as the number of residents drops. In effect, the hospitals will be paid not to train as many residents - much as the government pays farmers to let fields lie fallow when there is a surplus of corn.

Politicians and medical leaders agree that the United States is training too many physicians. Thirty-five years ago, there were just under 15,500 medical residents. By the academic year 1994-95, this number had increased more than sixfold to 103,000 . The challenge is to restrict the physician pipeline without forcing research hospitals to cut valuable programs. Because research hospitals have come to rely on the education revenues from Medicare, they stand to lose money if they do the right thing and reduce residency positions.

The Greater New York Hospital Association has come up with a plan to soften the blow that has left research hospitals in other states envious. The association has persuaded HCFA, which adminiters Medicare, to pay 41 New York hospitals a total of $\$ 400$ million between now and 2003 to reduce the number of approved residency positions for new physicians.

Bruce C. Vladeck, administrator of the Health Care Financing Administration, says the plan is "pathbreaking," and argues that it will pay off. He estimates that the $\$ 400$ million that the HCFA will pay New York's hospitals is actually $\$ 300$ million less than the cost of keeping the current number of residents in training over the same period.

Envy may turn to anger on Capitol Hill where some congressmen would like to stop HCFA from favoring New York at the expense of their home states. But rather than complain about New York's clever move, research hospitals in other states should work together to persuade the government to support them in the same way, says Jordan Cohen, president of the Association of American Medical Hospitals (AAMC).

BARBARA J. CUllitoN

\section{HIV CCR5 resistance incomplete}

Hopes that some people might be genetically protected from infection with HIV have been dampened by the findings of researchers in Australia. The findings confirm the fears of many scientists, who had warned people against abandoning safer sex on the basis of these hopes.

Last year there was widespread excitement when a chemokine receptor for HIV, known as CCR5, was discovered on certain immune cells. The excitement was fueled further when researchers found that people with an abnormal form of the receptor, resulting from two copies of a mutation in the gene encoding it, seemed to remain uninfected despite repeated exposure to the virus. But many scientists suspected that the mutation would not turn out to be completely protective, and their suspicions were borne out last month with the first report of a man who is homozygous for the CCR5 mutation but nonetheless infected with HIV (see Nature Medicine 3, 252; 1997).

The man, described by Graeme Stewart and his colleagues at the University of Sydney, may not be alone.
There are unpublished reports of one HIV-infected homozygote in France and one in the United States. However, the researchers suspect that these individuals are uncommon. "Infection of homozygotes is still likely to be a rare event," says Stewart. It will be impossible to predict accurately what proportion of homozygotes are infected until much larger numbers of people have been screened for the mutation.

Researchers have distinguished two broad "strains" of HIV: one that infects macrophages and some $\mathrm{T}$ cells, the socalled "M-tropic" strain, and one that prefers to invade T lymphocytes, the socalled "T cell-tropic" strain. The CCR5 receptor normally enables the M-tropic strain to enter these immune cells, but a 32-base pair deletion in the CCR5 gene produces an abnormal receptor that prevents them from gaining entry to the cells. However, the T cell-tropic strain continues to enter T cells, by using another receptor, known as CXCR4. Because researchers believe that most virus spread through sexual contact is from the M-tropic strain, they had cautiously reasoned that individuals ho- mozygous for the CCR5 mutation might be relatively protected from infection. The new results confirm their caution. "Although likely to be rare, the finding of an HIV-infected homozygote merely reinforces the importance of practicing safe behaviors at all times," emphasizes Richard Koup of the Aaron Diamond AIDS Research Center in New York city.

The Australian report raises more questions than it answers. "There are two possibilities," explains Bob Doms of the University of Pennsylvania. "The more exciting is that the original culprit was an M-cell tropic virus capable of using another chemokine receptor, such as CCR3, to establish an infection. Alternatively, this particular individual may have been initially infected with a $T$ cell-tropic virus strain that uses the CXCR4 receptor." Further studies are under way to determine the virus strain that originally infected the Australian homozygote. But this is likely to be a difficult task, as the virus has almost certainly mutated in the five years since the man was infected.

Apart from the CCR5 mutation, at least two other genetic mechanisms may influence individuals' susceptibility to HIV but after the virus has entered cells, rather than protecting against infection 